\title{
Výzkum efektivity výuky technických předmětů
}

\author{
Research of the efficiency of technical school subjects education
}

\author{
Karel Dvořák
}

\begin{abstract}
Abstrakt: Předkládaný př́spěvek popisuje výzkum prováděný při výuce odborných technických, strojírensky orientovaných předmětů na SPŠ a VOŠ. Výzkum probíhá na žákovských projektech virtuálních prototypů, vypracovávaných využitím CAx aplikací (Computer Aided Design, Engineering Manufacturing), používaných ve výuce i v průmyslové praxi. Výstupy žákovských projektů jsou výchozím zdrojem dat pro kvalitativní zkoumání technických dovedností, znalostí oboru a myšlení pro řešení problémů, odpovídajících jejich následnému profesnímu zařazení. Výsledky kvalitativního výzkumu jsou doplňovány zpracováním kvantitativních dat, zaměřených na teoretické znalosti posluchačů a jejich postoje k využívání CAx aplikací. Příspěvek objasňuje fáze výzkumu v souvislosti se získanými informacemi a v kontextu s cykly školní výuky. Komplexní vyhodnocení získaných výzkumných dat, vede k odpovědi na výzkumnou otázku: Posiluje výuka na projektech, podporovaná využitím CAx aplikací, mezipředmětové vztahy? V př́spěvku jsou dále popsány výchozí podmínky realizace výzkumu, získávání CAx dovedností žáků pro řešení zadaných úloh, př́prava zadávaných projektů a pravidla pro tvorbu $\mathrm{CAx}$ dat a jejich následnou analýzu.
\end{abstract}

Klíčová slova: počítačová podpora, virtuální prototypy, mezipředmětové vztahy, 3D datové modely, informační a komunikační technologie

\begin{abstract}
The contribution describes the research done during the education of vocational technical, engineering oriented subjects at SPŠ and VOŠ. The research is carried out on pupils' projects done by CAx applications (CAD, CAE, CAM) used in industrial practice. Outputs of the pupils' projects are default data source for qualitative research of technical skills, knowledge and thinking to solve problems of professional practice. Results of qualitative research are complemented by quantitative data analysis based on statistical evaluation of tests that are checking the theoretical knowledge of students and their attitudes to the use of CAx applications. Research phases are explained in connection with gained information and in the context of school education. An evaluation of research data answers the research question: Does the teaching on projects supported by the use of CAx applications strengthen cross-curricular links? The contribution also describes initial conditions for the realization of the research, students' acquisition of skills CAx for solving of assignments, preparation of entered projects and the establishment of rules for the creation of CAx data and their analysis.
\end{abstract}

Keywords: computer aid, virtual prototypes, cross-curricular links, 3D data model, information and communication technologies 


\section{1 Úvod}

Jednou z možností zvýšení efektivity a atraktivity výuky odborných technických předmětů na stř̌edních a vyšších odborných školách strojírenského zaměření je využívání didaktických technologií, které odpovídají současným trendům dispozic posluchačů a zároveň mají význam pro jejich zařazení do profesní praxe. Počítačová podpora technické př́ípravy výroby je využívaná několik desetiletí pro řešení úloh technické praxe. Př́prava technického personálu od úrovně středních škol si postupně vyžádala nasazení těchto aplikací ve výuce.

Předložený příspěvek představuje možnosti využití didaktického potenciálu nástrojů používaných v průmyslové praxi. Popisované technologie jsou nasazeny ve výuce odborných strojírenských předmětů na SPŠ a VOŠ (Dvořák, 2011). Efektivita koncepce výuky je předmětem probíhajícího výzkumu. Jsou představeny technologie, metodika výzkumu, doposud získané a vyhodnocené výsledky.

\section{CAx technologie}

Do skupiny CAx technologií řadíme softwarové nástroje pro podporu postupů zaměřených na vývoj, konstrukci, ověřování a technickou př́pravu výroby produktů. Využívané jsou zejména ve strojírenství, stavebnictví, elektrotechnice, ale také například ve zdravotnictví, logistice, apod. Př́spěvek je zaměřený na podporu výuky strojírenských předmětů.

CAx - Computer Aided technologies (schéma na obrázku 1) lze rozdělit na další podskupiny zaměřené na konkrétní činnosti. Ve výuce strojírenských předmětů jsou uplatňovány následující kategorie $\mathrm{CA}$ technologií:

- CAD - Computer Aided Design, tvorba datových 3D modelů a 2D výkresové dokumentace.

- CAE - Computer Aided Engineering, provádění analýz a simulací na modelech a sestavách vytvořených v CAD.

- CAM - Computer Aided Manufacturing, tvorba technologie, obvykle postupu obrábění na $3 \mathrm{D}$, nebo $2 \mathrm{D}$ datovém modelu výrobku.

Efektivní uplatnění nástrojů ve výuce, je podmíněno získáním základních dovedností práce v CAD, spočívající v ovládnutí portfolia funkcí a postupů dostatečných pro schopnost tvořit složitější konstrukce (Fořt \& Kletečka, 2007). 


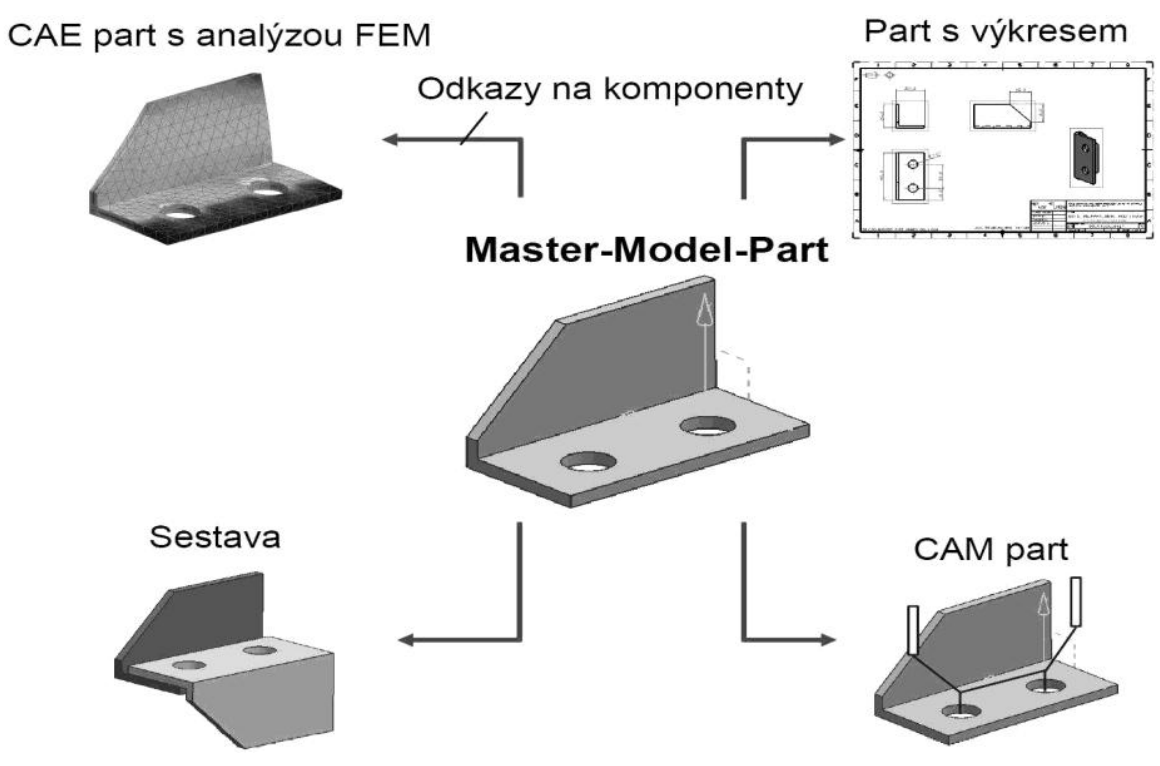

Obrázek 1. Možnosti a využití CAx technologií (Axiom Tech, 2007)

\section{Projekty virtuálních prototypů}

Digitální data 3D modelů a jejich sestav, vytvořených v CAD umožňují provedení celé řady analýz, simulací a dalších činností, prováděných na reálném výrobku (Fořt, 2010). Jde zejména o následující postupy:

- Vizualizace jednotlivých modelů.

- Vizualizace sestav a celků.

- Vizualizace souvislostí s pomocnými objekty (nástroji, referenční geometrií).

- Prostorové posouzení objekti̊.

- Měření modelů a sestav.

- Určení fyzikálních vlastností.

- Kinematická analýza mechanismů.

- Pevnostní a deformační kontrola namáhaných dílů.

- Návrh a ověření technologie výroby.

- Návrh a ověření technologie montáže.

Přínos uvedených činností v průmyslové praxi spočívá především ve zjednodušení procesů, zkrácení časů a snížení nákladů na materiál, logistiku a výrobu reálného prototypu. Ve školním prostředí je tento význam rozšířen ještě o možnost pochopení funkčnosti navržené konstrukce a získání základních zkušeností a dovedností při posuzování navrhovaných řešení.

Struktura systému směřujícího $\mathrm{k}$ výuce na projektech virtuálních prototypů $\mathrm{s}$ uplatněním mezipředmětových vztahů je na obrázku 2. 


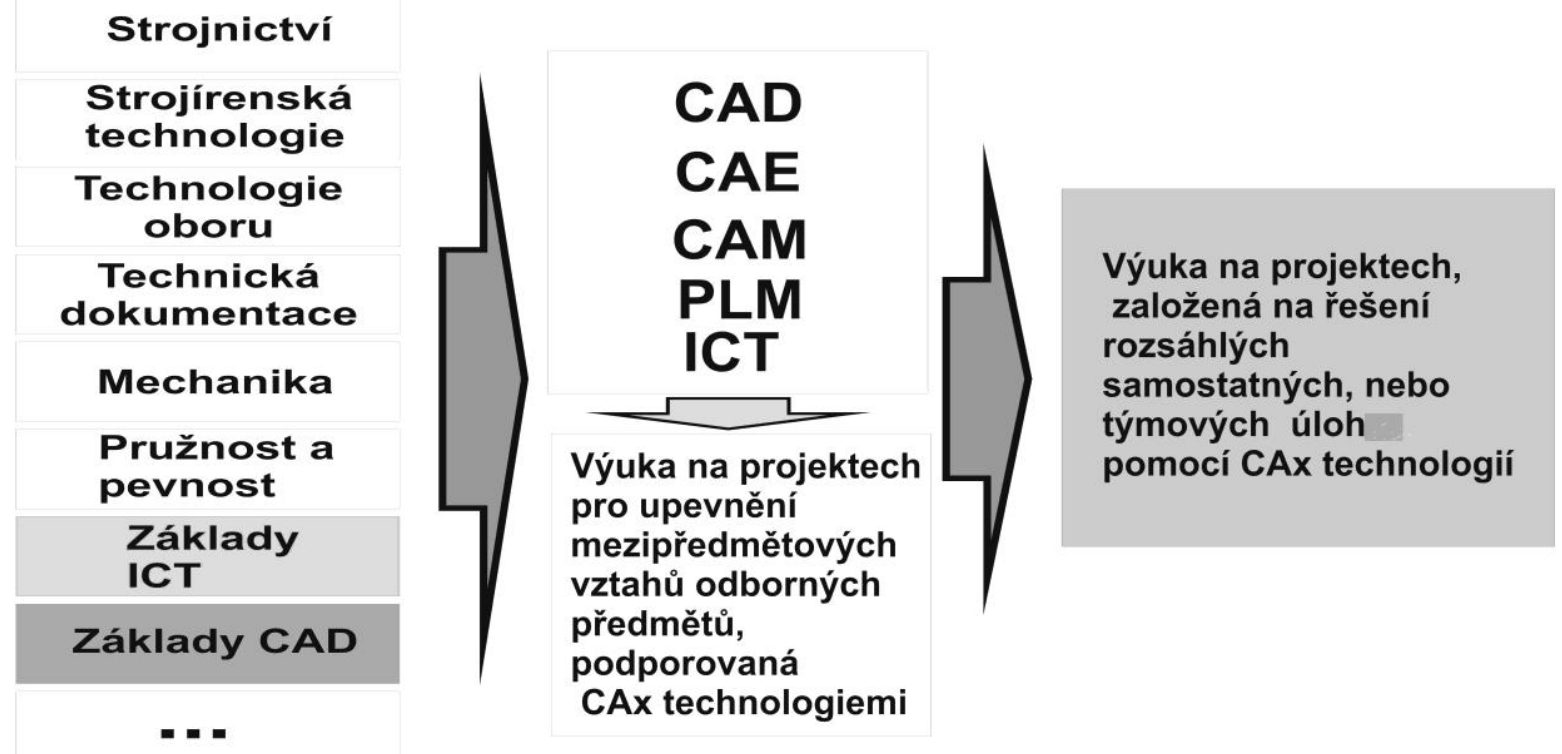

Obrázek 2. Koncepce výuky na projektech virtuálních prototypů.

\section{Výzkum efektivity výuky}

Výuka na projektech virtuálních prototypů předpokládá zvýšení znalostí a dovedností posluchačů a upevnění mezipředmětových vztahů v rámci oboru (Melezinek, 1994). Zároveň se očekává zvýšení jejich motivace pro studium zvoleného oboru a snadnější adaptace v profesní praxi. Výzkum je prováděn $\mathrm{v}$ průběhu výuky předmětů $\mathrm{CAD}, \mathrm{CAE}$ a ICT ve strojírenství na jedné skupině (Kerlinger, 1972) posluchačů vyšší odborné školy a střední průmyslové školy strojírenského a informačně-strojírenského zaměření.

Těžištěm je kvalitativní zkoumání postupů při práci na projektech virtuálních prototypů. Vstupní znalosti a dovednosti posluchačů jsou testovány na začátku práce na projektech. Důležitým faktorem je zadání parametrů projektu. Musí být zahrnuty postupy a kroky, které v dostatečné míře napodobí reálnou práci na komplexní úloze.

Cílem výzkumu je zvýšení efektivity výuky technického personálu využitím CAx aplikací ve výuce odborných technických, strojírensky orientovaných předmětů na středních a vyšších odborných školách.

Hlavní výzkumný problém klade otázku:

Posiluje projektově orientovaná výuka, podporovaná využiváním CAx aplikací mezipredmětové vztahy?

Prvotní aktivitou zaměřenou na výzkum efektivity výuky technických předmětů bylo vyhodnocení experimentu, provedeného $\mathrm{v}$ rámci výuky technologických předmětů a technické dokumentace oboru nástrojař na středním odborném učilišti strojírenském. Experiment vedl k definování následujících dílčích výzkumných problémů:

- Zvýší nasazení CAx technologií pro výuku odborných technických strojírensky orientovaných předmětů dovednosti absolventů pro řešení úloh průmyslové praxe?

- Zvýší práce s CAx aplikacemi tvořivost a aktivní př́ístup žáků?

- Zvýší intenzivní využívání CAx aplikací ve výuce motivaci žáků ke studiu strojírenské problematiky? 
Výzkum je prováděn na následujících skupinách

- Žáci technických oborů středních průmyslových škol strojírenského zaměření.

- Posluchači technických oborů VOŠ v rámci výuky a v rámci odborné praxe.

- Absolventi SŠ a VOŠ po nástupu do technické praxe.

Uvedené skupiny jsou rozdělovány na kontrolní a experimentální. Výběr do jednotlivých skupin je provedený s cílem rovnoměrného zastoupení žáků dle jejich dispozic. V žádné skupině nepřevažují žáci dobří, nebo naopak slabší. Provedené experimenty v rámci předvýzkumu a úvodní kvalitativní vyhodnocení průběhu a výsledků žákovských projektů vedly ke generování a formulování následujících hypotéz:

H1: Využití CAx aplikací ve výuce technických předmětù vede ke zvýšení znalostí a dovedností absolventů pro řě̌eni strojirenských konstrukčnich úloh.

H2: Výuka podporovaná CAx aplikacemi vede ke zvýšení motivace posluchaču pro studium technické problematiky.

Platnost hypotéz je ověřována statistickým vyhodnocením dat, získaných dotazníkovým šetřením a kvantifikací vybraných sledovaných parametrů, zachycených hloubkovou analýzou dat dokončených žákovských projektů. Dotazníkové šetření je prováděno na více vybraných strojírensky a informačně-strojírensky zaměřených školách v České republice. Dosažení statistické významnosti je provedeno opakovaným prováděním šetření na žákovských projektech. Sběr dat pro kvalitativní analýzu a následnou kvantifikaci výsledků je prováděn při výuce na projektech v rámci předmětů $\mathrm{CAD}, \mathrm{CAE}$ a ICT ve strojírenství na SPŠ a VOŠ ve Žd'áru nad Sázavou.

\section{Kvalitativní analýza CAD/CAE dat žákovských projektů}

Č́stečnou odpověd’ na výzkumné otázky koncepce výuky technických předmětů může dát kvalitativní analýza výstupů žákovských projektů. CAD/CAE data jsou nosičem velkého množství informací, popisujících zejména:

- Historii vzniku datového modelu a použité postupy.

- Teoretické konstruktérské znalosti a dovednosti.

- Teoretické technologické znalosti a dovednosti posluchače.

- Znalost technických norem, pravidel a doporučení.

- Potenciální funkčnost navrhovaného řešení.

K vytvoření návrhu virtuálního prototypu obvykle vede více cest a postupů. Rozbor aktuálního stavu vypracování 3D dat a analýza topologie historie návrhu je doplněna pozorováním řešitelů v průběhu semestru, nebo pololetí školního roku. Projekt je zadán tak, aby $\mathrm{s}$ přidělenou časovou dotací na práci $\mathrm{v}$ předmětu bylo možné jej dokončit, nebo vypracovat do stadia dostatečného pro hodnocení a analýzu.

Součástí dat k vyhodnocení efektivity výuky je také vyhodnocení pretestu a posttestu (Kerlinger, 1972) obecných znalostí strojírenské problematiky a průběžné testování CAx dovedností žáků. 


\section{Kvantitativní šetření postojů posluchačů k problematice CAx aplikací}

Zjišt'ování úrovně motivace ke studiu strojírenské problematiky a postojů posluchačů $\mathrm{k}$ progresivním nástrojům informačních technologií je opřeno o statistické vyhodnocení dat, získaných prostřednictvím testů a dotazníkovým šetřením mezi žáky strojírenských oborů na středních technických školách a vyšších odborných školách. Informace jsou získávány z více oborově zaměřených škol v ČR následujícími technikami:

- Papírové dotazníky, rozdané posluchačům při výuce.

- Elektronické dotazníky, zaslané e-mailem.

- Prostřednictvím webového formuláře (preferované).

Přesto, že základem celého výzkumu je kvalitativní analýza CAx dat, statistická zjištění kvantitativních dat mohou být zdrojem informací pro optimalizaci výuky a projektů, na kterých bude v následných fázích prováděno kvalitativní šetření.

Dotazníky a testy jsou zaměřené zejména na zjištění následujících faktorů:

- Výchozí znalosti 2D a 3D CAD nástrojů.

- Výchozí dovednosti práce s ICT.

- Dovednosti základních 2D a 3D CAD postupů.

- Představa o CAE, CAM technologiích.

- Výchozí teoretické znalosti základů strojírenství.

- Motivace ke studiu zvoleného oboru.

- Motivace k profesionálnímu uplatnění ve studované oblasti.

- Zvýšení zájmu o studium strojírenství v důsledku využívání CAx technologií.

\section{Dosavadní zjištění v kontextu probíhajícího výzkumu}

Digitální data dokončených projektů virtuálních prototypů představují významný soubor výzkumných informací. Kvalitativním šetřením historie aktivit, souvisejících se průběhem řešení projektu, lze zaznamenat rozvoj dovedností posluchačů. Dovednosti se týkají zejména efektivní práce s nástroji pro design - CAD a ověření těchto návrhů prostřednictvím nástroje pro simulace - CAE. Původní předpoklad souběžného růstu znalostí strojírenské problematiky se vyhodnocením dosud získaných dat nepotvrdil. Předpoklad nelze přijmout ani na základě vyhodnocených posttestů. Pro dosažení statistické významnosti bude nutné provést opakovaný sběr dat při dodržení stejných podmínek, jako u předchozího výběru. Kvantifikace parametrů pro statistické vyhodnocení bude provedena po dosažení odpovídajícího počtu vzorků. V pokračujících fázích výzkumného šetření bude pozornost soustředěná zvlášt' na znalosti a dovednosti při paralelním zjišt'ování motivace posluchačů. Průběžné výsledky šetření jsou použité k optimalizaci struktury zadávání žákovských projektů. Z projektů byly odstraněné požadavky, jejichž dodržení při vypracování neposkytuje relevantní informaci. Pozornost je zaměřená na prvky, u kterých se předpokládá rozšíření sobouru výzkumných dat, především pro kvantifikaci a statistické vyhodnocení. U absolventů, kteří získali uplatnění v profesní praxi studovaného oboru byla sledována jejich adaptace, zejména samostatnost při řešení předložených úkolů a celková pracovní výkonnost. Absolventi od začátku uplatňovali získané dovednosti a v porovnání s absolventy stejných oborů, kteří neabsolvovali výuku dle popisované koncepce, vykazovali výrazně lepší kvalitativní výsledky. 


\section{Závěr}

Těžištěm výzkumu efektivity výuky technických předmětů prostřednictvím CAx aplikací je kvalitativní šetření v průběhu výuky na projektech. Vyhodnocená výzkumná data naznačují zvýšení efektivity výuky upevněním mezipředmětových vztahů a získávání praktických návyků, které jsou obvykle získávány až v průběhu profesní praxe po absolvování studia.

CAx data obsahují velké množství informací, které mohou být východiskem pro provádění dalších výzkumů, orientovaných na měření výkonů žáků, vytváření struktur vědomostí, motivace ke studiu a dalších psychologických a sociologických aspektů technického vyučování. Určitý potenciál zde může být i pro výzkum ve výuce některých přírodovědných předmětů.

\section{Seznam literatury}

Dvořák, K. (2011). Projektově orientovaná výuka, podpořená strategii PLM. IT CAD, 21(1) 36-37. Dostupné z http://www.cad.cz/home/casopis-it-cad.html?rocnik=2011\&id=82

Fořt, P., Kletečka, J. (2007). Autodesk Inventor, funkční navrhování v prümyslové praxi. Brno: Computer Press.

Fořt, P. (2010). Řešení žákovských projektů pomocí PLM technologii. (Závěrečná práce). Brno: Mendelova univerzita, Institut celoživotního vzdělávání.

Kerlinger, F. N. (1972). Základy výzkumu chování: pedagogický a psychologický výzkum. Praha: Academia.

Melezinek, A. (1994). Inženýrská pedagogika. Praha: ČVUT.

Axiom Tech. (2007). NX drafting, modeling, assemblies. Žd'ár nad Sázavou.

\section{Kontakt}

Ing. Bc. Karel Dvořák

Univerzita Hradec Králové

Pedagogická fakulta

Rokitanského 62, 50003 Hradec Králové

e-mail: karel.dvorak@uhk.cz

\section{Bibliografické údaje}

Dvořák, K. (2011). Výzkum efektivity výuky technických předmětů. In T. Janík, P. Knecht, \& S. Šebestová (Eds.), Smíšený design v pedagogickém výzkumu: Sborník př́spěvků z 19. výroční konference České asociace pedagogického výzkumu (s. 250-256). Brno: Masarykova univerzita.

Dostupné z: http://www.ped.muni.cz/capv2011/sbornikprispevku/kareldvorak.pdf doi: 10.5817/PdF.P210-CAPV-2012-8 